\title{
Method and Theory in Religious Studies: Retrospect and Prognostications
}

\author{
MORNY JOY \\ University of Calgary
}

\begin{abstract}
There is a distinct possibility that, in the twenty-first century, Religious Studies as a discipline could come into its own. Its multidisciplinary orientation, if handled with due critical awareness as to its own former grandiose ambitions and present entanglements, could provide insight into the various problems that beset contemporary existence. Religious Studies has been involved in a number of internal debates that have sapped its energies and prevented it from advancing theoretically in ways that would help it address these problems. In this article I survey some of the developments that have taken place in other disciplines that could be of benefit in helping Religious Studies take its place as a discipline that is relevant for the twenty-first century.
\end{abstract}

Keywords: Religious studies, cultural studies, culture, postcolonialism, gender

If one surveys the present conditions of Planet Earth, the inevitable conclusion is that it is facing a number of challenges that threaten its continued viability as a life-enhancing environment - in climatic as well as in humanistic matters. From a pessimistic perspective, the human species seems bent on destroying itself, from diverse forms of over-indulgence or acrimonious hostilities, in which religion is all too often invoked as the justification. Terms such as the 'clash of civilizations', the 'axis of evil', and other banal slogans are declaimed as a cause for national and religious self-righteousness. The crucial question arises as to what the appropriate contribution of Religious Studies could be in these dire circumstances. This depends, however, on finding a way to move beyond certain retroflexive theoretical and methodological issues that have held the discipline in thrall. One need look no further than the work of Malory Nye to find an apt definition of what has ailed the discipline. In an article published in 2000, Nye defines the problem. 
My impression is that scholars of religion have been so taken up with perpetuating and maintaining a discipline of religious studies for themselves vis-à-vis theology and theologians that they have failed to notice that the wider vista outside these narrow confines has been rapidly changing.

[...] It seems that the politics of perpetuating religious studies as a discipline has taken priority over any sustained attempt to examine the political strategies that underlie the construction of religion as an object (Nye 2000, 451-2).

My own musings on this topic were stimulated by my participation at a recent conference in Stockholm, held at Södertörn University College (19-22 May 2007), entitled: 'Religion on the Borders: New Challenges in the Academic Study of Religion'. As part of the research for my paper, I came across an intriguing statement by Fredric Jameson where he contrasted the definition of a border with that of the frontier. In discussing the notion of the frontier in the late nineteenth century in the Americas, he says:

The frontier was the moveable (Westward) landmark of the march of the civilising mission, the line dividing civilization from barbarism. The frontier [...] was not only geographic but epistemological as well: the location of the primitive and the barbarian was the 'vacant land', from the point of view of the economy, and the 'empty space' of thinking, theory and production. (Jameson 1998, 45.)

Jameson contrasts this with the contemporary appeal to a border or borderlands mentality, where these terms feature as an alternative to the restrictions and reductions imposed by frontiers. He coins the term 'border gnosis' to refute the claims of the frontier's former civilizing mission and to promote instead the counterclaims of the once excluded 'barbarians'. For Jameson, '[b]order gnoseology (rather than epistemology) in all its complexity (geocultural, sexual, racial, national, diasporic, exilic, etc.) is a new way of thinking that emerges from the sensibilities and conditions of everyday life created by colonial legacies and economic globalization' (Jameson 1998, 46). ${ }^{1}$

\footnotetext{
${ }^{1}$ Jameson, who is not a fan of postmodernism, may not necessarily approve of another current usage of the term 'border' which is employed in postmodernism in connection with the idea of 'border crossing'. Best and Kellner describe this movement: 'The paradigm shift from disciplinary to transdisciplinary approaches has spilled over into manifold realms of theory, the arts and the sciences. Cross-disciplinary border crossing is evident in the field of literary criticism, where a number of essays and books have explored the connections between quantum mechanics, chaos theory and postmodern fiction and literary theory.' $(1997,258$.) Though this usage is of interest, it is not the concern of this essay.
} 
This mode of postcolonial critical thinking is echoed by another contributor to the volume on Globalization in which Jameson's essay appeared. In his essay, 'Beyond Eurocentrism', Enrique Dussel endorses a position from the periphery, according to an ethics of liberation, which positions itself as 'transmodern'. Such a position allows for the reclamation of certain components of modernity, but at the same time rejects the excesses of this 'civilizing system' as they continue to escalate and exhaust themselves in today's world of late-capitalist global profiteering: 'The overcoming of cynical managerial reason (planetary administrative), of capitalism (as economic system), of liberalism (as political system), of Eurocentrism (as ideology), of machismo (in erotics), of the reign of the white race (in racism), of the destruction of nature (in ecology), and so on presupposes the liberation of diverse types of the oppressed and/or excluded' (Dussel 1998, 19). Dussel is also wary of postmodernism because he views it as essentially still a Eurocentric movement and therefore not sufficiently critical $(1998,19)$. Instead, Dussel proposes the notion of 'transmodernity' as a version of pluralism or multiculturalism that would replace both modernity and postmodernity. Dussel's revisionist Marxist critique puts into sharp relief the ravages that he believes have been inflicted on the world by today's global capitalist economy. Such exploitation, in his view, parallels the devastation caused by the conquistadors of former centuries. It would seem that religion, as an agency of such 'civilization' would be high on his list of rejections. Dussel, however, is both a philosopher and theologian of liberation; thus there is an aspect of religion that he thinks could be redeemed, together with certain other uncompromised elements of modernity. ${ }^{2}$

In a similar vein to this proposed recuperation of certain elements of religion, a relevant question might be asked about the discipline of Religious Studies. One could enquire as to what could be salvaged from the criticisms to which it has been subjected in recent years. For it is not only religion, but Religious Studies itself, that has also been charged with being an accessory to the crime of the colonial civilizing activities - and such an accusation is not made by postcolonial scholars alone. The work of numerous theorists, such as Timothy Fitzgerald (2000), Richard King (1999) and Donald Lopez (1998), has indicted the discipline for its inclusivist tendency to classify other religions from its own normative (Christian) position. This reductive trend incorporated all the trappings of an imperialist, missionizing orientation in its imposition of regulative categories that either exoticized or caricatured

2 I leave to Dussel and other theologians the task of reclaiming religion itself, which is a distinctly theological one. My own interest is solely in the discipline of Religious Studies. 
the religious practices of other peoples - when it was not in the service of conversion. In addition, other critics, such as Daniel Pals (1987) and J. Z. Smith, have taken the discipline to task for its assertions of a sui generis particularity both in its approach and its essentialist pretensions. Another shortcoming noted by Smith is its partiality for pronouncing redundant platitudes in the formulation of its findings (Smith 2001).

Despite these objections, I do not think that the term 'religion' needs to be jettisoned from Religious Studies as irretrievably compromised. Instead, it makes more sense to me to incorporate these criticisms into the methodological study of religions. I prefer this tactic rather than searching for seemingly less compromised names or concepts by which to label the practices that indicate the conduct, attitudes, and systems of thought or belief that until now have gone by the designation of 'religion'. In this endeavor, I am in agreement with Jeppe Sinding Jensen when he declares:

'Religion' is out there in the world, and it makes sense to use the term in spite of all the ideological loadings disclosed by conceptual and genealogical analyses. For all its historicity and contingency, it is as real as anything else in the (post)modern world, and there is no need to worry about or lament this state of affairs unless one longs for foundational verities. (Jensen 2003, 413.)

Religious Studies, like most other disciplines that were conceived as a result of the modernist impulse, brings with it the inevitable biased presuppositions that informed the period. No western discipline from that time has emerged unscathed. Such a history - with all of its colonial baggage - requires critical evaluation. In this exercise, I think it is appropriate to keep the observations of Talal Asad firmly in mind - particularly when he advocates that, though he does not necessarily recommend reducing the meaning of religious practices and utterances to social phenomena, a thorough examination of its modernist historical pedigree is absolutely necessary. He notes:

To understand better the local people's 'entering' (or 'resisting') modernity, anthropology must surely try to deepen its understanding of the West as something more than a threadbare ideology. To do that will include attempting to grasp its peculiar historicity, the mobile powers that have constructed its structures, projects, desires. I argue that religion, in its positive and negative senses, is an essential part of that construction. (Asad 1993, 23.) 
This is indeed a tall order, but I think it addresses the crux of the matter at hand. As an anthropologist, Asad recognizes the inevitable complex, interactive, even mutually reinforcing dimensions that can inhere in the formation of any entity or identity. He also emphasizes the equally intricate and multiple forces at play in any received definition of such entities and identities as part of the production of knowledge. (It would seem that today even knowledge itself has become commodified. $)^{3}$ In the unpacking of these constituents, there is no innocent or ideal position from which to start, as all parties involved are complicit to some degree. Asad's critical approach does not allow for unreconstructed conclusions nor for protestations of innocence, let alone a stance of detached superiority. Much long and hard work is required to even begin to counter such positions.

\section{The Return of the Repressed: Religion?}

In the meantime, however, something unanticipated has occurred that merits as much attention as the consternation about the less than auspicious foundations of Religious Studies. This is the fact that religion itself has made a surprising return in the last half of the twentieth century, confounding modernity's predictions of its imminent demise. Some pundits have attributed this to a lack of awareness or non-acceptance of the Enlightenment's rigorous critique of religion; others regard it as a desperate response to the banality of the capitalistic commodification of culture; while yet a few view it as a last-ditch lifeline, in reaction to the exponential rate of change set in motion by the technical/technological revolution. The results of this development have not been greeted positively. Terry Eagleton $(2007,40)$ vents his displeasure:

The more religion loomed up as an alternative to the steady haemorrhaging of public meaning, the more it was driven into various forms of fundamentalisms. Or if not that, then into new Ageist claptrap. Spirituality, in short, became either rock-hard or soggy.

Eagleton's unenthusiastic appraisal is part of his lament for the vapid nature of contemporary culture, which he defines as 'largely a matter of how to keep people harmlessly distracted when they [are] not working' $(2007,39)$.

\footnotetext{
${ }^{3}$ Evidence of this component of consumer culture abounds. It can be detected in the requisite sound bites that have come to dominate much US news and other packaged forms of information in newspapers and on the web; in books on various topics sold as guides for 'dummies'; in many universities in North America where students are referred to as 'clients' and advertisements for Presidents often are worded as searches for CEOs.
} 
He views this triteness as part and parcel of the present-day preoccupation with material production and the capitalistic machinations of desire, as manifested specifically in an increasingly globalized economy. Surely one of the responses that could be made on the part of Religious Studies is not simply to undertake a neutral study of such phenomena, but also to offer a cultural critique of this banalization of religion. This trivialization is not unique to religion, but is a major aspect of contemporary western culture itself, as it has succumbed to the whims of an instrumentalist version of cultural exploitation. Only a handful of scholars in religion, however, have ventured into this territory. ${ }^{4}$

In their book Selling Spirituality (Carrette \& King 2005), Jeremy Carrette and Richard King detail the emergence of a mode of 'consumerist' or 'capitalist spirituality' and then make such a recommendation. They describe their misgivings about the movement whereby 'Religion is rebranded as "spirituality" in order to support the ideology of capitalism' (Carrette \& King 2005, 17). According to the authors,

this cultural ordering of spirituality in the business world exploits the transformative power of traditional 'spiritual' disciplines by reorienting their fundamental goals. In this context, spirituality becomes a way of developing incentives that are conducive to the corporate objectives of the employer. The 'spiritual' becomes instrumental to the market rather than oriented towards a wider social and ethical framework, and its primary function becomes the perpetuation of the consumerist status quo rather than a critical reflection on it. (Carrette \& King 2005, 23.)

What they support is a cultural critique, along the lines of those proposed by Jameson and Dussel, that takes such blatant commodification and exploitation to task. They consider that such a critique is needed because few, if any, of the academic commentators on the emergence of such a market-oriented spirituality evaluate this development, preferring to adopt a neutral descriptive stance. It needs to be noted that Carrette and King are not supportive of any return to a naïve, idealized appreciation of religion; they acknowledge its inevitable involvement with both politics and economics in today's world. They are, instead, troubled by the fact that the ideological manipulation of free-market rhetoric and practices, so characteristic of globalization, simply reenacts former colonialist practices. They justify their critical approach by

\footnotetext{
${ }^{4}$ Peter Beyer is one of the few scholars who has written on religion and globalization. The approach he employs in his three books, $(1994 ; 2001 ; 2006)$, is from the perspective of sociology of religion and thus differs from mine. He uses systems theory analysis to chart the interfaces of religion with the globalization process, which is viewed as a continuation of modernity.
} 
a statement that appeals to Foucault's ideas of permitting the emergence of other, less controlling forms of expression:

We do this, not because we wish to appeal to some kind of ancient 'authentic' or 'true' spirituality to which they do not conform [...] but rather to open up a contested space that will allow alternative, more socially engaged, constructions of the term to express themselves (Carrette \& King 2005, 5).

Yet even assuming such a task is not undertaken from a moralistic and/or defensive perspective, a number of obstacles suddenly become apparent. Foremost among these is the issue of the understanding of the term 'culture' itself, as part of a method of cultural critique. This has been a topic that has been at the centre of a major debate among anthropologists and other social scientists for a few decades, but Religious Studies has scarcely even addressed the issue. Given the fact that some of its harshest critics have suggested that one possible alternative to the term 'Religious Studies', would be a variant of 'Cultural Studies', it does seem particularly apposite to undertake at this stage a survey of the word 'culture'. On the one hand, such a survey could help clarify the way that 'culture' might feature in a revised understanding of Religious Studies as it mobilizes itself to participate in significant debate about the place and role of the discipline in the twenty-first century. On the other hand, however, a genealogical analysis in the manner of Foucault could provide evidence that as a term,'culture' itself is just as contaminated as 'religion'.

\section{Disrupting Culture}

Perhaps, as a preliminary step, it would be worthwhile to take the measure of the discipline of Cultural Studies itself as it features in the repertoire of many English-speaking universities today. Simon During has provided a masterful survey of the development of Cultural Studies in his Introduction to a reader he edited, appropriately entitled The Cultural Studies Reader (1993). He traces its expansion from the beginnings in Great Britain in the mid-fifties, when it came into being as an interdisciplinary approach that introduced a deliberate form of cultural critique. In this context, the term 'culture' was originally and implicitly accepted as indicating 'a way of life' that was specific, in this instance, to the lower or working class of Great Britain - particularly its local or traditional mores and attitudes. Yet, as this class began to prosper in the sixties, Cultural Studies' Marxist underpinnings took a more philosophical turn, so that importations such as Antonio Gramsci's concept of 'hegemony', became an influential, if not 
ubiquitous term. This promoted an analysis of the changing cultural values of the working class, with an emphasis on resistance to external impositions as exemplified by the icons of mass or middle-class culture. In time, under certain French influences - most importantly those of semiotics and structuralism ${ }^{5}$ - there was a turn away from the promotion of lower-class preoccupations towards an interest in the status of other groups of people who were regarded as marginal and excluded, e.g., gays and lesbians. The term 'otherness' came into vogue and took on various forms of articulation. (During 1993, 2-17.) ${ }^{6}$ One of the subsequent developments in the eighties was that this new focus also became centred on the 'culture' of those who had come to Great Britain as immigrants, or of external communities who were regarded as inferior and thus relegated to the position of the 'other'. During himself documents this change, which was largely motivated by a reaction to the neo-Conservative programmes of Margaret Thatcher:

Conceiving of cultural studies as the academic site for the marginal minority discourses had another, very different but no less visible and globalizing consequence, one which took it further from its original attack on mass culture. The discipline began to celebrate commercial culture, in a move I will call 'cultural populism'. Cultural populism became possible within the cultural studies anti-hegemonic tradition because, despite the new right's reliance on values disseminated through the cultural market, the right also buttressed its monoculturalism by traditionalist appeals to the canon. (During 1993, 17.)

Such a turn, however, also brought about a somewhat unexpected expansion as well as conservative effects:

In its turn, cultural populism helped cultural studies to become global just because $[\ldots]$ commercial culture has an increasingly transnational reach.

\footnotetext{
${ }^{5}$ During cites Pierre Bourdieu, Michel de Certeau and Michel Foucault as the principal influences of this movement $(1993,10)$.

${ }^{6}$ The term 'otherness' and its associated term, différance, a key term in Derrida's strategy of deconstruction, came into focus as a central concept in both cultural critique and postmodernism. In its current guise it arose principally from phenomenology - though the basic idea of otherness as negativity had been in circulation since Hegel - as a way of acknowledging the diverse modes by which knowledge is acquired by interaction with another. It need not always have positive connotations, as in Sartre's formula of 'Hell is other people'. It does, however, mark a distinct move from solipsism to a relational identity. Postmodernism changed the emphasis to that of an excluded other - be it a person, thing, or even a meaning - that can exert a disruptive influence on any presumed ideal entity or finalized definition.
} 
What form has cultural populism taken in cultural studies? It too turned away from the highly theoretical attacks on hegemony so important in the 1970s, this time by arguing that at least some popular-cultural products themselves have positive quasi-political effects independently of education and critical discourse. (During 1993, 17.)

This change of emphasis has in turn led to a number of strange, if not schizophrenic eventualities in some branches of Cultural Studies, particularly as the discipline has emerged in North America. In this new geographical setting it has tended to take on the trappings of 'Popular Culture'. From one perspective, there are still remnants today of its former critical position, when it does take to task the blatant commodification of culture, with the understanding that a critique still has the ability to instigate transformative change. In yet another direction, cultural studies can seem to consist of nothing more than a crass celebration of material quirkiness or the products of popular taste and mass consumption. Religious Studies has not yet imitated this movement, though a general haziness can be detected whenever some scholars try to discuss the products of religious culture in a general sense. For this reason, I believe that there are important lessons to be gained by a study of the somewhat bizarre co-existence of these two seemingly contrary impulses in contemporary Cultural Studies in North America. What needs to be further explored, and then studied as a cautionary tale, is the rationale - or lack of one - that has led to this seeming capitulation by an academic discipline to accepting the manufactured desires of the market place as a given, without questioning either their provenance or their consequences.

This strange move, that appears to capitulate to crass commercialization, has not gone unnoticed by cultural commentators such as Eagleton, as evidenced by his earlier comments on contemporary culture. One of the things that becomes immediately obvious when reading such critical contemporary assessments of the effects of a globalized economy is an awareness that the idea of culture itself has altered dramatically. As yet, however, Religious Studies does not seem to have taken sufficient cognizance of this change, despite the growing amount of work now available that is of marked relevance for religion. In an article entitled "“Culture” and Human Rights: Orientalising, Occidentalising and Authenticity', Martin Chanock draws attention to this shift. He first examines the traditional meaning of culture, where it was viewed from an ahistorical perspective as an entity that exhibited qualities of 'permanence, stability and temporal depth'. By way of contrast, Chanock observes that today ' $[\mathrm{t}]$ he concept of culture has become 
a prime way of describing groups and is displacing other primary labels like race, class, gender or nationality at a particular time and in particular circumstances' (Chanock 2000, 18). This development appears to denote a type of atavistic urge to proclaim a distinct identity as a protection against increasing globalization - thus functioning as a variant of identity politics. Chanock links this development to a move whereby

[t]he cultural rejection of human rights [viewed as a modernist project] is now not based on national differences but assumes that above and beyond national distinctiveness (based on language, place, historical association and narrative, and so on), there is something larger - European, Asian, African; or Christian, Muslim, Confucian - which distinguishes people from each other. The first of these looks suspiciously like a different way of talking about racial differences, while the second not just invokes broad differences in 'civilizations' but links them to the possession of religious truths. (Chanock 2000, 18.)

In this guise, culture thus appears to have become synonymous with tradition so as to provide a bulwark of conservatism against any change - especially that associated with 'western' values. In some instances this claim to tradition is connected with appeals to a pristine or idealized form of religion that predated colonialization. ${ }^{7}$

Chanock is somewhat suspicious of this move, viewing such appeals to authenticity on the part of a culture, tradition or religion as itself a type of manufactured, modernist undertaking, involving the 'invention of tradition' and the 'imagining of [ideal] communities' (2000, 27). While Chanock understands that the battle for survival in the globalized marketplace may influence such constructions, he worries about the false polarizations that are thereby being created and exploited. This can be seen in the organized opposition to human rights by a number of constituencies, who view them as just one more product or weapon in the arsenal of contemporary U.S. imperialism/globalization. As a result, false accusations abound, resulting in the further fabrication of false dichotomies. One example of such an artificial polarity is illustrated by the claims of religion/tradition that are pitted against the humanist platform of human rights. On the side of tradition, religion is posited as an endangered species of culture, while human

\footnotetext{
${ }^{7}$ In her book, Dislocating Cultures, Uma Narayan describes the manner in which such claims function in contemporary forms where there is movement to unite nationalism with religion, as in India. She is as concerned about the 'demonic other' produced by colonialism as she is about the ensuing manufactured nostalgic essentialism of an idealized, ancient India (1997, 142-57).
} 
rights, on the other, are portrayed as the humanist panacea for the myriad ills of a political and economic nature that beset many developing nations. A stalemate ensues. ${ }^{8}$ This is because both sides become locked into postures that prevent a careful exploration of the historical and philosophical realities behind the rhetoric. Chanock concludes his paper with a timely reminder, echoing the admonitions of the cultural commentators quoted earlier:

All we can say about 'culture' comes from a history of imperialism, and from the current dual framework of 'orientalising' and 'occidentalising' in a world of globalised symbolic exchange. If we are to treat 'culture' as a fundamental factor in our analyses of rights, and of government and institutions [religion and Religious Studies included], we need a very high degree of self-awareness of the history and current circumstances of the deployment of the concept. (Chanock 2000, 35.)

The call for a critical and historical analysis as endorsed by Chanock is absent from most present-day discussions in Religious Studies on the idea of culture. Yet it seems that the term 'culture', just as much as that of 'religion', is subject to the same harmful influences resulting from the legacy of colonialism. It is also particularly ironic that the former professed ideals of impartiality and benevolence on the part of colonial powers are now being reappropriated by certain countries and/or religions to defend their own 'culture' as a bastion of integrity. In a fascinating twist, conservative religions appear to be adopting a well-honed colonial strategy. Given its own precedents, it would seem that any contemporary study of religion's imperial tendencies and their after-effects would be bound to investigate all present-day evidence of such behaviour. As a result, any scholar who claims to study these developments from a standpoint of impartiality or neutrality should be suspected of either benighted ignorance or outright dishonesty. ${ }^{9}$

As an illustration of a discipline where an attempt has been made to incorporate such a self-reflexive awareness into both method and theory in response to this challenge, anthropology provides a sterling example. Nye has drawn a particularly graphic comparison between the advances made in anthropology and the lack of them in Religious Studies:

\footnotetext{
${ }^{8} \mathrm{I}$ have discussed the damaging effects of such a polarization in current committees at the United Nations, where women's access to human rights is being opposed by fundamentalist forms of a number of religions. See Joy (2006, 19-27).

${ }_{9}$ Narayan discusses the various camouflages that can be affected by scholars pretending to undertake disinterested study of other cultures. See her analysis of such types as the 'Emissary', the 'Mirror', and the 'Authentic Insider' (1997, 121-57).
} 
The meeting ground between anthropology and cultural studies has produced a very rich field of theoretical and methodological engagements that have created a large measure of critical reflection on the discursive and political contextualities of the empirical research through which cultural contextualizations are generated. It is precisely with this general field that I would recommend that the discipline of religious studies be developed, rather than risk the very real possibility that the academic production of knowledge within the discipline become increasingly isolated from other humanities subject approaches. (Nye 2000, 471-2.)

The absurdity of any claim to a neutral study of other peoples' cultures is captured nicely in an anecdote related by Sally Engle. She describes a situation where she was asked by a reporter to comment on a case in Pakistan where a young woman had been gang-raped in retaliation for a crime committed by her brother. This act had been authorized by the local council. The reporter wanted a statement that would justify the council's decision to impose such punishment on the grounds of its traditions and culture. Engle comments:

The interviewer was distressed. She wanted me to defend the value of respecting Pakistani culture at all costs, despite the sentence of rape. When I told her that I could not do that, she wanted to know if I knew of any other anthropologists who would. I could think of none, but I began to wonder what she thought about anthropologists and their views of culture. She apparently assumed that anthropologists made no moral judgments about 'cultures' and changes taking place within contemporary local communities around the world. (Engle 2006, 7.)

Engle's further comment presents with unambiguous clarity not simply the unedifying spectacles of past and present appeals to such an uncritical appreciation of culture, but the requisite critical approach that is essential today to counter such misrepresentations. She states ironically:

Apparently cultures have no contact with the expansion of capitalism, the arming of various groups by transnational superpowers using them for proxy wars, or the cultural possibilities of human rights as an emancipatory discourse. I found the interviewer's view of culture wrong-headed and her opinion of anthropology discouraging. (Engle 2006, 7.) 
Engle's own position on culture reflects the on-going debates that have taken place in anthropology, particularly during the last twenty years on the subject of 'culture', and the movement away from any timeless ahistorical definition that is devoid of context. She prefers to work within a framework that is more accommodating of external influence and change:

The prevailing understanding of culture within contemporary anthropology envisions a far more fluid and changing set of values and practices. [...] Over the last two decades, anthropology has elaborated a conception of culture as unbounded, contested, and connected to relations of power, as the product of historical influences rather than evolutionary change. Cultural practices must be understood in context, so that their meaning and impact change as their context shifts. (Engle 2006, 14-15.)

Such an understanding reflects the changes in anthropology since the work of James Clifford, whose work helped to redefine the role of an anthropologist. He regarded an anthropologist not so much a detached observer, but rather as one who situates him- or herself within a historically constituted world, only too aware that one's own worldview is similarly subject to such vicissitudes as those one studies. As I stated in Joy (2000, 132), 'Clifford acknowledges the seemingly paradoxical modes of engagement in ethnography as it both negotiates and evaluates the very procedures it both introduces and participates in'. This self-reflective stance, which scrutinizes one's own presuppositions, would seem to provide a distinctly appropriate model for scholars in Religious Studies. This is principally because, as Clifford (1988, 2-3) observes, '[a]nthropology no longer speaks with automatic authority for others unable to speak for themselves ("primitive", "preliterate", "without history")'. No scholar can presume that his or her interpretation constitutes an exact representation of the worldview he or she has studied, or the people he or she has interviewed.

\section{Disputing Gender}

There is one further problematic related to 'culture' that also needs to be addressed if this term is to be of any further use to the discipline of Religious Studies. This is the term 'gender' - which seems to have had almost as checkered a history as 'culture' and has undergone a similarly critical interrogation in anthropology. This is probably because gender was traditionally treated as a sub-set of culture. As Henrietta Moore explains: 'The implication [during the 1970s and 1980s] was that since all cultures defined, 
constructed and enacted gender in specific ways, each culture had its own distinctive gender system.' She then continues and qualifies this observation: 'However, recent work in anthropology has demonstrated that cultures do not have a single model of gender or a single gender system, but rather a multiplicity of discourses on gender that can vary both contextually and biographically.' (Moore 1994, 56.) Such an approach marked a break from a generally accepted yet stereotypical theory of socialization whereby gendered characteristics were imposed according to a biological distinction between the two sexes. The present direction of gender studies is towards a more nuanced and flexible view, where sex is no longer regarded as merely biological and gender is not simply a matter of social construction. Both sexual and gender differentiation are now understood as susceptible to degrees of social management.

This more variegated approach has also helped to initiate a break from the type of static correlation that was first posited by Sherry Ortner in her classic essay: 'Is Female to Male as Nature to Culture?' (1996 [1972]). The position promoted by Ortner's paper appeared to state that universal male dominance could be explained by positing such an analogy. At the time, Ortner tried to explain her position without resorting either to a strict sense of biological determinism, or to the exclusion of women from participation in culture. She nevertheless still typecasts women as having an intimate relation to nature that men did not have.

Women's physiology, more involved more of the time with 'species life'; women's association with the structurally subordinate domestic context, charged with the crucial function of transforming animal-like infants into cultured beings; 'woman's psyche', appropriately molded to mothering functions by her own socialization and tending towards greater personalism and less mediated modes of relating - all these factors make woman appear to be rooted more directly and deeply in nature. (Ortner 1996, 38.)

Such a comparison of a bifurcated model of male/female characteristics with a culture/gender divide only served to reinforce the binary system that underlay the sex/gender distinction. Basically the problem with such a functional analysis was that it was then generalized as symptomatic of most cultures. This description failed to consider the particular forces at work - be they political, religious, or economic - that led to the formation of such structures within a given society. At the same time, there was no self-reflection on the part of the anthropologist concerning the limitations of the specific theory and method employed in her/her own analysis of that 
society. As Ortner herself admits in a later retrospective appraisal of her own essay: 'Behind my rethinking are larger shifts in the conceptualization of "culture" in the field of anthropology as a whole, in the direction of seeing "cultures" as more disjunctive, contradictory, and inconsistent than I had been trained to think' (Ortner 1996, 175).

This more flexible understanding is evident in recent scholarship on the term 'gender', which has undergone a number of important revisions. In Joy (2006) I surveyed a number of these changes with reference to Religious Studies. Gender can no longer simply be an all-purpose term, assigned to 'masculine' and 'feminine' modes of behaviour that are regarded as correct for members of a specific biological sex. In a manner that is similar to Ortner's changed view of culture, gender is now regarded as a somewhat malleable category rather than a normative prescription. It can also be applied in a critical mode, as in gender analysis, where naturalized attributes and customs are submitted to careful scrutiny. Joan Scott, an American critical theorist, provides a template of the way that gender can be employed as an agent of interrogation in her work, Gender and the Politics of History (1999 [1988]). Scott believes that the following questions should always be posed from a critical analytic perspective:

How and under what conditions [have] different roles and functions been defined for each sex; how [have] the very meanings of the categories 'man' and 'woman' varied according to time and place; how [were] regulatory norms of sexual deportment created and enforced; how [have] issues of power and rights played into questions of masculinity and femininity; how [do] symbolic structures affect the lives and practices of ordinary people; how [were] sexual identities forged within and against social prescriptions (Scott 1999, xi).

Again, Religious Studies has been slow to adopt such theoretical developments, involving a critical and evaluative moment that goes beyond a simple questioning of the suitability of the application of a given method.

The approach of gender analysis has been used by a number of women scholars in religion. It is in this area of women's and gender studies, however, that there still seems to be a rather fascinating division in the discipline of Religious Studies. Despite the valuable work being done by women in many aspects of history, anthropology, philosophy and sociology, as well as religion, where highly sophisticated gender research has been undertaken - little, if any, of this work is acknowledged by male scholars in their own writing. This is particularly evident in the area of method and theory, where 
a perfunctory chapter on gender and feminist theory is considered sufficient. In the past, the omission of women and women's scholarship could be excused because of the exclusion of women from the halls of learning. This is no longer an acceptable excuse.

\section{The Postmodern Turn}

In a number of ways all of these changes in method and theory that I have proposed reflect the postmodern turn. Yet I need to be extremely careful not to make any blanket endorsement of the adoption of such an approach. This is because postmodernism is just as contested a site as the terms 'culture', 'gender', and 'religion' themselves. Fredric Jameson, who is not enthusiastic about postmodernism, and who went so far as to describe it as the quintessential expression of the superficiality of late modern capitalism (1984), nevertheless concedes that there is a need to enter into negotiations with it under certain conditions:

The concept is not merely contested, it is also internally conflicted and contradictory. I will argue that, for good or ill, we cannot not use it. But my argument should also be taken to imply that every time it is used, we are under the obligation to rehearse those inner contradictions and to stage those representational inconsistencies and dilemmas: we have to work that through every time around. Postmodernism is not something that we can settle once and for all and then use with a clear conscience. (Jameson 1991, xxii.)

In the spirit of contestation that Jameson advises, I would thus like to examine certain critical postmodern strategies that I think have been employed or described in the course of this paper. In so doing, I want to propose that these specific tactics would be most appropriate for the tasks that are facing Religious Studies if it is to advance beyond navel-gazing. I also undertake this exercise in the spirit of Terry Eagleton, another cultural critic who is not enthusiastic about postmodernism, but who recognizes that there are some positive aspects to its implementation in certain contexts:

Postmodernism is not, of course, just some sort of theoretical mistake. It is among other things the ideology of a specific historical epoch of the West, when reviled and humiliated groups are beginning to recover something of their history and selfhood. This, as I have argued, is the trend's most precious achievement. (Eagleton 1996, 121.) 
In full awareness that this is not in any way a ringing endorsement, and that what Eagleton fears most of all is relativism, I want to explore the work of two thinkers labeled as postmodern, Jacques Derrida and Michel Foucault, even if both of them were reluctant to identify with this brand. What I want to examine in particular are specific instances of their respective critical stances which I believe reinforce - basically because they were largely influential in the process - the changes that have taken place in anthropological method and theory. I believe the aspects of their work that I analyze are of immense relevance for theory and method in Religious Studies.

The intricacies of the early work of Jacques Derrida defy easy encapsulation, but the ideas expressed in his later writings on religion in particular have a pertinence for this study. In an essay in the volume Religion (1998) that he co-edited with Gianni Vattimo, resulting from a conference held on Capri, Derrida investigates the contemporary phenomenon of the 'return of religion'. Employing deconstructive tactics, he delves deeply into what is understood by this turn of phrase, especially the meaning of the term 'religion'. In doing so, Derrida puts into question a number of things, among them the unacknowledged presupposition of the conference that the religion that is under discussion is actually the Christian religion, with its masculinist monopoly. This monopoly is also reflected in the sex of the conference participants. Derrida even comments: 'Not a single woman!' $(1998,5)$. He also wonders at the seemingly unquestioning acceptance of this Christian orientation, illustrated by the absence of representatives from any other religions - especially Islam (p. 5). (Derrida concedes that there is a nominal representation of Judaism - no doubt due to his own presence.) He remarks on the homogeneity of the participants - all are Europeans, mostly from Mediterranean countries. While he acknowledges that they are indeed beneficiaries of the Enlightenment, he nonetheless detects a certain Latin legacy. This leads him to muse that such a legacy reflects the unquestioned imperial supremacy of the Roman empire, whose accoutrements of colonizing behaviour also seem to have been assumed at this conference (p. 4-7). Finally he worries about the 'military interventions' that are being undertaken by a contemporary 'colonizing' empire in connection with the 'return to religion' and its political and liberatory slogans against 'terrorists'. He appreciates this move as having distinct ties with what he terms 'an essentially economic and capitalistic rationality' that operates in conjunction with a 'tele-techno-scientific machine' that is the engine of contemporary globalization. (Derrida 1998, 45.) 
Derrida is obviously very much alert to the imposition of rigid boundaries that exclude others, and that are accompanied by exclusionary language, e.g. religion being equated with Christianity; other peoples and religions being designated as 'the axis of evil'. In this context, Derrida puts deconstruction to work to dismantle the false dichotomies that have been constructed to justify struggles that are far from disinterested and differ greatly from their ostensibly stated aims. They reflect the types of injustice that were formerly inflicted by frontier-colonizing depredations, as mentioned by Jameson at the beginning of the essay, and that, under the guise of imposing western culture, largely destroyed the ways of life intrinsic to those who were conquered - or rather, 'civilized'.

Michel Foucault's early work has been dismissed by some critics as a mode of nihilism in the tradition of Nietzsche, especially in connection with his alleged 'death of the subject' (Foucault 1985, 102). But such a reading is far too simplistic; what Foucault is questioning is the unreflective assumption of identity and agency as an entitlement. This form of self-sufficient righteousness, in Foucault's estimation, does not take into account the matrices of power that allow such an arrogation to occur. Foucault describes his own strategy in an interview:

What I refused was precisely that you first of all set up a theory of the subject - as could be done in phenomenology and existentialism - and that, beginning from the theory of the subject, you come to pose the question of knowing. [...] I had to reject a certain a priori theory of the subject in order to make this analysis of the relationships which can exist between the constitution of the subject and games of truth, practices of power and so forth. (Foucault in Bernauer \& Rasmussen 1988, 10.)

Foucault asserts that there can be no easy assertion of such a right to such power without an awareness of the various exclusions that have been created by such a maneuver. Foucault's investigations are undertaken so as to detect the voices of peoples who have been silenced in order for a single self-prepossessing subject to emerge. Foucault never denies that there is subjectivity. He nevertheless wants to demonstrate the abuses that can occur when it is presumed that such a subject has qualities of permanence and control. His intention is to encourage more self-reflexivity of the manner in which such an identity is constituted by multiple influences, which inevitably are determined by specific interests - cultural, political, or religious. Foucault's intentions become more apparent in his later work, where he 
is concerned with delineating the ways in which a subject or self can be cultivated in self-critical ways that do not necessarily exploit others. As Foucault himself relates:

I would say that if now I am interested, in fact, in the way in which the subject constitutes himself in an active fashion, by the practices of the self, these practices are nevertheless not something that the individual invents by himself. They are patterns that he finds in his culture and which are proposed, suggested and imposed on him by his culture, his society and his social group. (Foucault 1985, 11.)

From Foucault's perspective, there needs to be a critical awareness that these practices are never neutral. He carefully differentiates between the various types of power that can be involved in any given society as well as the appropriate critical tools that need to be brought to bear on such influences: 'On the critical side - I mean critical in a very broad sense - philosophy is precisely the challenging of all phenomena of domination at whatever level or under whatever form they present themselves - political, economic, sexual, institutional, and so on' (Foucault 1985, 20). Though Foucault doesn't specifically mention religion in these regimes of power, his work is a crucial reminder that all definitions and structures are of a disciplinary nature, and need to be similarly scrutinized in a philosophically critical manner.

In these brief and highly selective references to the work of both Derrida and Foucault, which focus on their questioning of received knowledge, what is being recommended is an orientation that is suspicious of false presumptions to authorial privilege and the imposition of definitions according to predetermined categories of dubious provenance. Such a critical method is extremely cogent for contemporary studies in religion. While this is not an unequivocal recommendation on my part of the unilateral use of a postmodern strategy, I think that there are certain tools of a critical nature in its repertoire that could be integrated very effectively into both theoretical and methodological approaches in Religious Studies, and that could prove most salutary.

\section{Conclusion}

Religious Studies may well be a compromised discipline because of its implication in the civilizing ministry of modernity. In this, however, it shares its suspect inheritance with all the other disciplines that were generated by modernity's optimistic project of bringing European enlightenment to 
the 'uncivilized'. As scholars of religion, our own involvement - conscious or otherwise - in this complicated inheritance is a given. Religious Studies may well also be complicit - as I have also argued elsewhere (Joy 2000) - in present-day global economic enterprises of an unsavory nature. Most scholars who are employed by universities which operate according to the tenets of economic rationalism participate to some degree in such practices. Given such occupational hazards, what is a poor scholar to do? Perhaps a healthy dose of postmodern suspicion, supplemented by cultural critique, could prove to be therapeutic. One consequence of acknowledging such inevitable connections with tainted goods, even if not deliberately, is that no more time need be spent searching for a new, less guilty term, or some irreproachable substitute, for the word 'religion' and for the discipline of Religious Studies. What I would encourage instead, is a more strenuous study of the contemporary ills that beset such 'civilization' as has thus far been achieved - with all its betrayals, exploitation and concessions, as well as certain elements of modernity that, as Dussel attests, may merit reclamation.

In particular, more attention needs to be paid to other disciplines, such as anthropology, that have introduced a healthy self-reflexive approach that is necessary if Religious Studies is to be of relevance in today's world. The work of contemporary critical theorists on globalization and its discontents, such as Roland Robertson (1992), Saskia Sassen (1998), Richard Falk (2001), Marguerite Waller \& Sylvia Marcos (2005), Arjun Appadurai (2005), and George Rupp (2006), in addition to those mentioned in this essay, would also furnish pertinent material for further reflection. There are indeed scholars who are endeavoring to engage honestly with the challenge that globalization brings, including its capitalist rapacity and the ensuing displacement of human beings, livelihoods, and resources. If taken seriously, these changes could well require a rethinking of the terms of reference for the discipline of Religious Studies. It is not simply the meaning of 'culture' and 'gender' that need to be revised, but the mode of thinking that has been content to insist on neutrality or objectivity, when all too often - in both past and present - this has simply been an excuse for unacknowledged interests. Religious Studies as a discipline has also been content to remain satisfied with false dichotomies and simplistic dualisms that categorize, to the point of distortion, the entities that they create by their descriptions. It has in addition become embroiled in its own 'cultural wars' between various proponents of a secular social scientific approach. They continue to squabble amongst themselves concerning the most efficacious way of limiting the incursions 
of theology upon their territory. While I am no supporter of theology in Religious Studies, I find these debates are not particularly productive. All of these complacencies and insular preoccupations have prevented Religious Studies from addressing in critical and constructive ways the issues of life and death that are confronting humanity today. Not that I anticipate that there will be any immediate or easily reached conclusions on these matters. As Terry Eagleton has sagely observed: 'Modernity [...] is the epoch in which we come to recognize that we are unable to agree even on the most vital, fundamental of issues' (Eagleton 2007, 175). Postmodernism in its less helpful adaptations may have exacerbated such a trend. But at least we could begin to be open to advances that have been made in other disciplines that could energize and even revitalize Religious Studies.

\section{Bibliography}

Appadurai, Arjun (ed.)

2005 Globalization. Durham NC: Duke University Press.

Asad, Talal

1993 Genealogies of Religion: Disciplines and Reasons of Power in Christianity and Islam. Baltimore: Johns Hopkins University Press.

\section{Bernauer, James \& David Rasmussen (eds)}

1988 The Ethic of Care for the Self as a Practice of Freedom. An Interview with Michel Foucault on January 20, 1984. - The Final Foucault, 1-20. Cambridge, MA: MIT Press.

\section{Best, Steven \& Douglas Kellner}

1997 The Postmodern Turn. New York: The Guilford Press.

\section{Beyer, Peter}

1994 Religion and Globalization. London: Sage Publications.

2001 Religion in the Process of Globalization. Würzburg: Ergon Verlag.

2006 Religions in Global Society. London: Routledge.

\section{Carrette, Jeremy \& Richard King}

2005 Selling Spirituality: The Silent Takeover of Religion. London: Routledge.

\section{Chanock, Martin}

2000 Culture and Human Rights: Orientalising, Occidentalising and Authenticity. - Mahmood Mamdani (ed.), Beyond Rights Talk and Culture Talk, 15-36. New York: St. Martin's Press. 


\section{Clifford, James}

1988 The Predicament of Culture: Twentieth-Century Ethnography, Literature and Art. Cambridge MA: Harvard University Press.

\section{Derrida, Jacques}

1998 Faith and Knowledge: The Two Sources of 'Religion' at the Limits of Reason Alone. - Jacques Derrida \& Gianni Vattimo (eds), Religion, 1-78. Stanford CA: Stanford University Press.

\section{During, Simon (ed.)}

1993 The Cultural Studies Reader. London: Routledge.

\section{Dussel, Enrique}

1998 Beyond Eurocentrism: The World System and the Limits of Modernity. - Fredric Jameson \& Masao Miyoshi (eds), The Cultures of Globalization, 3-31. Durham, NC: Duke University Press.

\section{Eagleton, Terry}

1996 The Illusions of Postmodernism. Oxford: Blackwell Publishers.

2007 The Meaning of Life. A Very Short Introduction. Oxford: Oxford University Press.

\section{Engle, Sally Merry}

2006 Human Rights and Gender Violence: Translating International Law into Local Justice. Chicago: University of Chicago Press.

\section{Falk, Richard}

2001 Religion and Humane Global Governance. London: Palgrave.

\section{Fitzgerald, Timothy}

2000 The Ideology of Religious Studies. Oxford: Oxford University Press.

\section{Foucault, Michel}

1985 The Use of Pleasure: The History of Sexuality, Vol. II, translated by Robert Hurley. New York: Pantheon.

\section{Jameson, Fredric}

1984 Postmodernism, Or, The Cultural Logic of Late Capitalism. - New Left Review, 146 (July-August), 59-92.

1991 Postmodernism, Or, The Logic of Late Capitalism. Durham: Duke University Press.

1998 Notes on Globalization as a Philosophical Issue. - Fredric Jameson \& Masao Miyoshi (eds), The Culture of Globalization, 54-77. Durham NC: Duke University Press.

\section{Jensen, Jeppe Sinding}

2003 The Study of Religion in a New Key. Aarhus: Aarhus University Press. 


\section{Joy, Morny}

2000 Beyond a God's-Eye View: Alternative Perspectives in the Study of Religion. - Armin W. Geertz \& Russell T. McCutcheon (eds), Perspectives on Method and Theory in the Study of Religion, Adjunct Proceedings of the 17th Congress of the International Association for the History of Religions. Leiden: Brill.

2006 Gender and Religion: A Volatile Mixture. - Temenos 42(1), 7-30.

\section{King, Richard}

1999 Orientalism and Religion: Postcolonial Theory, India and 'the Mystic East'. London: Routledge.

\section{Lopez, Donald}

1998 Prisoners of Shangri-La: Tibetan Buddhism and the West. Chicago: University of Chicago Press.

\section{Moore, Henrietta}

1994 A Passion for Difference. Oxford: Polity Press.

\section{Narayan, Uma}

1997 Dislocating Cultures, Identities, Traditions, and Third World Feminisms. New York: Routledge.

\section{Nye, Malory}

2000 Religion, Post-Religionism, and Religioning: Religious Studies and Contemporary Cultural Debates. - Method $\mathcal{E}$ Theory in the Study of Religion 12, 447-76.

Ortner, Sherry B.

1996 Making Gender: The Politics and Erotics of Culture. Boston: Beacon Press.

\section{Pals, Daniel}

1987 Is Religion a Sui Generis Phenomenon? - Journal of the American Academy of Religion 55(2), 259-82.

\section{Robertson, Roland}

1992 Globalization: Social Theory and Global Culture. London: Sage Publications.

\section{Rupp, George}

2006 Globalization Challenged: Conviction, Conflict, Community. New York: Columbia University Press.

\section{Sassen, Saskia}

1998 Globalization and its Discontents. New York: New York Press. 
Scott, Joan Wallach

1999 (1988) Gender and the Politics of History. New York: Columbia University Press.

Smith, Jonathan Z.

2001 A Twice-Told Tale: The History of the History of Religions' History. - Numen 48, 131-46.

Waller, Marguerite \& Sylvia Marcos (eds)

2005 Dialogue and Difference: Feminists Challenge Globalization. London: Palgrave Macmillan. 